\title{
Bronze Age catastrophe and modern controversy: dating the Santorini eruption
}

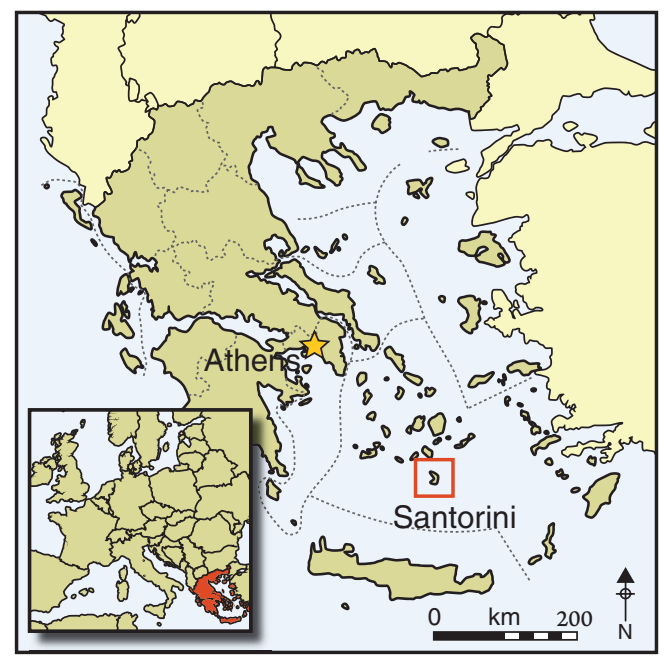

The date of the volcanic eruption of Santorini that caused extensive damage to Minoan Crete has been controversial since the 1980s. Some have placed the event in the late seventeenth century $B C$. Others have made the case for a younger date of around $1500 \mathrm{BC}$. A recent contribution to that controversy has been the dating of an olive tree branch preserved within the volcanic ash fall on Santorini. In this debate feature Paolo Cherubini and colleagues argue that the olive tree dating (which supports the older chronology) is unreliable on a number of grounds. There follows a response from the authors of that dating, and comments from other specialists, with a closing reply from Cherubini and his team.

Keywords: Santorini, Thera, Minoan eruption, radiocarbon dating, tree-rings

\section{The olive-branch dating of the Santorini eruption}

Paolo Cherubini ${ }^{1}$, Turi Humbel ${ }^{1,2}$, Hans Beeckman ${ }^{3}$, Holger Gärtner ${ }^{1}$, David Mannes ${ }^{4}$, Charlotte Pearson ${ }^{5,6}$, Werner Schoch ${ }^{1}$, Roberto Tognetti ${ }^{7} \&$ Simcha Lev-Yadun ${ }^{8}$

\section{Introduction}

The massive eruption of the volcano beneath the island of Thera (Santorini) in the middle of the Aegean Sea provides a fundamental datum point in the history of the Late Bronze Age civilisations of the eastern Mediterranean (Figure 1). The archaeological remains excavated at Akrotiri include impressive architecture, remarkable wall-paintings and large numbers of other finds and provide an unparalleled view of Aegean civilisation in the middle of the second millennium BC (Doumas 2010). The eruption occurred close to the height of the power and influence of the civilisation centred on Minoan Crete. Chronology is of major 

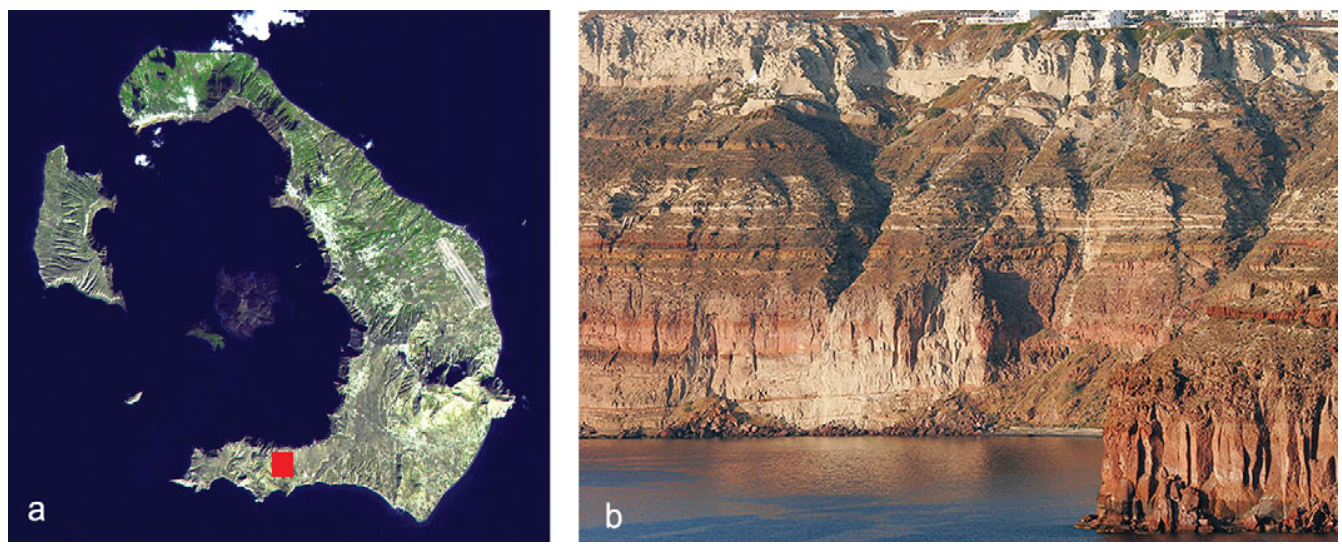

Figure 1. a) Satellite view of Santorini, showing the shape of the volcanic caldera (C)NASA; Akrotiri is marked with a square); b) an example of the volcanic layers found across Santorini (C) Tom Pfeiffer/www.volcanodiscovery.com).

importance for understanding the interconnections and influences between the ancient civilisations of the Aegean, Egypt and the Near East. The eruption has been dated near to the beginning of the New Kingdom in Egypt by a range of archaeological evidence. This dating appears to be strongly supported by the presence and sequence of Egyptian artefacts found in the Aegean as well as by large amounts of Cypriot pottery of various phases found both in Egypt and in one notable case also in the Theran volcanic destruction layer. It is also supported by the presence of pumice sourced to the Theran eruption in archaeological contexts in Egypt, the Near East and Cyprus (Doumas 2010), whereas all pumice found in earlier contexts has been sourced to other, earlier eruptions in the Dodecanese (Manning et al. 2006, 2009; Friedrich \& Heinemeier 2009; Friedrich et al. 2009; Heinemeier et al. 2009).

Over the past 40 years, various studies have cited proxy evidence (ice-core acidity peaks and tree-rings) to place the Thera eruption around a century earlier, in 1628 or 1650 BC (LaMarche \& Hirschboeck 1984; Baillie \& Munro 1988). These apparent proxy connections (Pearson et al. 2009) are difficult to substantiate. They have recently gained apparent support (e.g. Manning et al. 2006, 2009; Friedrich \& Heinemeier 2009; Friedrich et al. 2009; Heinemeier et al. 2009) from the publication of radiocarbon dates based on

1 WSL Swiss Federal Institute for Forest, Snow and Landscape Research, Zürcherstrasse 111, CH-8903 Birmensdorf, Switzerland (Email: paolo.cherubini@wsl.ch (author for correspondence), holz.schoch@woodanatomy.eu, holger.gaertner@wsl.ch)

2 Department of Geography, University of Zurich, Winterthurerstrasse 190, CH-8057 Zürich, Switzerland (Email: turihumbel@gmail.com)

3 Laboratory for Wood Biology and Xylarium, Royal Museum for Central Africa, Leuvense Steenweg 13, B-3080 Tervuren, Belgium (Email: hans.beeckman@africamuseum.be)

4 PSI Paul Scherrer Institute, CH-5232 Villigen, Switzerland (Email: david.mannes@psi.ch)

5 The Malcolm and Carolyn Wiener Laboratory for Aegean and Near Eastern Dendrochronology, B-48 Goldwin Smith Hall, Cornell University, Ithaca, NY 14853-3201, USA (Email: c.pearson@cornell.edu)

6 Bryant Bannister Tree-Ring Building, The University of Arizona, 1215 E. Lowell Street, Tucson, AZ 85721-0400, USA (Email: c.pearson@ltrr.arizona.edu)

7 Department of Science and Technology of the Environment and Territory, University of Molise, I-86090 Pesche, Italy (Email: tognetti@unimol.it)

8 Department of Biology \& Environment, Faculty of Natural Sciences, University of Haifa-Oranim, Tivon 36006, Israel (Email: levyadun@research.haifa.ac.il)

(C) Antiquity Publications Ltd. 


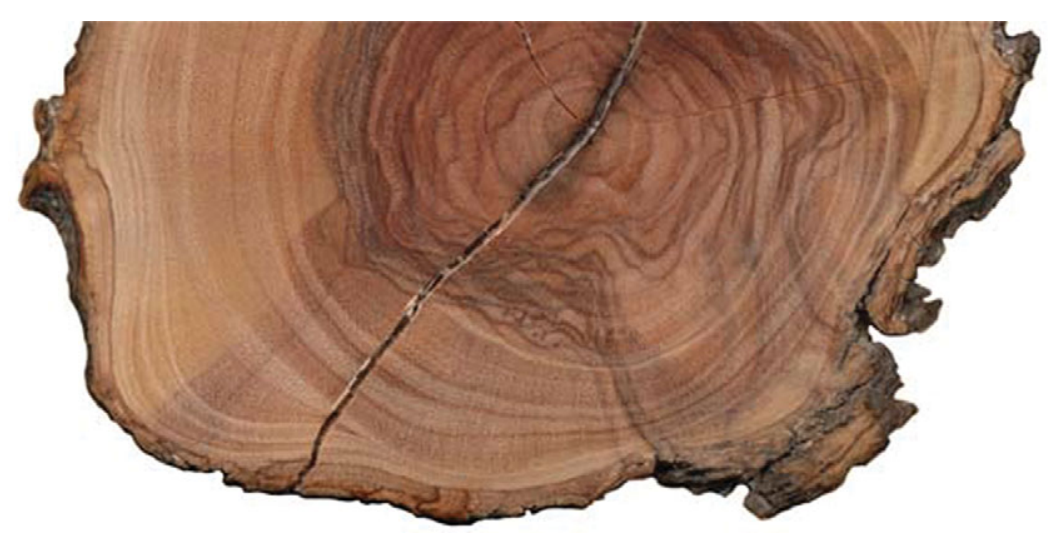

Figure 2. Cross-section of olive wood. Note the indistinct annual rings, caused by a lack of seasonality due to mild Mediterranean winters. Image: Turi Humbel.

the putative tree-ring sequence of a single olive branch buried in the tephra on Thera (Friedrich et al. 2006). This evidence has itself been the subject of extensive dispute (Warren 2006, 2009; Wiener 2009a \& b). These discussions focused on the oscillating nature of the radiocarbon calibration curve over the relevant period, which makes it impossible to distinguish on radiocarbon grounds alone between an event around $1610 \mathrm{BC}$ and one around $1525 \mathrm{BC}$. Radiocarbon measurements from tree samples of this period securely dated by dendrochronology, e.g. German oak, give similar radiocarbon ages for the decades centred on 1605, 1585, 1575, 1555, 1535 and 1505 BC, as do Anatolian junipers from Gordion for 1620, 1570, and 1540 BC (Wiener 2010).

Advocates of the earlier date have claimed that a series of measurements from the island of Thera in particular provide ${ }^{14} \mathrm{C}$ ages somewhat higher than $c .1610 \mathrm{BC}$. These measurements have, however, been the subject of considerable controversy with respect to their claimed accuracy of \pm 8 years. The volcanic nature of the island of Thera also adds uncertainty regarding the possible effects of carbon reservoir depletion on ${ }^{14} \mathrm{C}$ values in the atmospheric air used for photosynthesis. In areas of the world where the necessary analysis of the volcanic atmosphere has been undertaken, such as Italy, radiocarbon from tree-rings gives dates that are a century or more early (Carapezza et al. 2009; Wiener 2010). Against this background, the radiocarbon measurements from the olive tree branch found buried in the eruption layer on Thera have added a new dimension to the discussion and have been considered critical evidence in the view of many (Warren 2009, 2010; Wiener 2009a \& b, 2010).

Friedrich et al. (2006) reported the finding of a charred olive tree branch that they assume to have been alive when buried in tephra during the Minoan-period eruption. The authors of that study, aware of the fact that olive trees form irregular, barely identifiable tree-rings (Figure 2), used a 3D high-resolution X-ray Computer Tomography (CT) to define a putative 72-year tree-ring sequence on the cross-section of the olive branch that was to be radiocarbon dated. Wiggle-matching of four radiocarbon measurements from this branch against the calibration curve derived from other trees of known date (IntCal04) led them to assert that the calibrated age range of the outermost tree-ring of that olive branch was 1627-1600 BC (Friedrich et al. 2006). 
The claim to have successfully wiggle-matched the ${ }^{14} \mathrm{C}$ sequence to the tree-ring chronology is critical to this proposal, inasmuch as the radiocarbon measurement from Santorini by itself is subject to the well-established 'reservoir effects' of ${ }^{14} \mathrm{C}$-deficient carbon that characterise many volcanic islands and surrounding seas (Saurer et al. 2003; Carapezza et al. 2009; Frezzotti et al. 2009). It is highly probable that there were significant emissions of much more ancient pre-eruption volcanic $\mathrm{CO}_{2}$ that were ${ }^{14} \mathrm{C}$-depleted and fixed by the tree's photosynthesis and incorporated into its tree-rings (Saurer et al. 2003; Donders et al. 2013).

The assertion of a reliable ${ }^{14} \mathrm{C}$ 'wiggle-match' dating for Santorini is crucially dependent on the ability precisely to identify annual tree-rings in olive trees. In order to date the eruption, the tree-rings of the olive branch should reliably represent actual individual years, i.e. be annual tree-rings. That is not always the case in olive trees (Arnan et al. 2012). The last ring must also be contemporary with the volcanic eruption, i.e. from a live branch and not a dry, dead one that would reflect an earlier period. This in itself is a problematic issue in mature olive trees.

The results of a blind test involving several tree-ring laboratories to date tree-rings from olive trees currently growing on Santorini (Cherubini et al. 2013) clearly showed that measurements of tree-rings in olive wood from Santorini are highly unreliable owing to: a) intra-annual wood density fluctuations (e.g. Cherubini et al. 2003; Battipaglia et al. 2010; De Micco et al. 2012; Rossi et al. 2013); b) variability in tree-ring boundary structure (De Micco et al. in press); and c) restriction of cambial activity to shifting sectors of the circumference (Rossi et al. 2013), causing the tree-ring sequences along radii of the same cross sections to differ. We conclude that the dating of the Thera eruption based on the putative tree-ring sequence from a single olive tree must be considered with great caution.

\section{Discussion}

Ten tree-ring experts took part in the study to determine the number of tree-rings in olive trees currently growing on Santorini. The average number of tree-rings counted by the ten experts showed maximal deviations between 24.5 per cent to 56.3 per cent from the median, showing high variability among different experts' results (Cherubini et al. 2013). Even high-quality Neutron imaging of the tree-rings or SXFM mapping of elemental intensity for $\mathrm{Ca}$ failed to identify alternate elemental patterns within the xylem which might have been used to distinguish true annual tree-rings from inter-annual density fluctuations. Therefore, identification of olive wood tree-rings from Santorini by any means was found to be practically impossible.

A difference of 44 per cent-the average deviation in the olive tree-ring measurements by the ten experts-in the 72 putative tree-rings described by Friedrich et al. (2006) would result in a range of 40 to 104 years, rather than 72 as proposed. In contrast, Friedrich et al. (2006) estimate a maximal possible error of \pm 3 years for each of the four segments of the olive branch examined, giving a total of \pm 12 years. The results of Cherubini et al. (2013) pose a severe challenge to Friedrich et al's method and their dating of the Santorini eruption from a single olive branch tree-ring sequence and radiocarbon wiggle-match analysis. Without a safe identification of annual tree-ring boundaries there can be no certainty about the ${ }^{14} \mathrm{C}$ (C) Antiquity Publications Ltd. 
dating. An erroneous wiggle-match leads inevitably to incorrect results. In this respect, even the very modest \pm 3 years claimed by Friedrich $e t$ al. is sufficient to cast doubt on their wiggle-match analysis.

Friedrich et al. knew about the difficulties of dating olive wood and tried to overcome them by using 3D high-resolution X-ray Computer Tomography (CT). They also presented a model in which they took these difficulties into account: they "... allow for a counting uncertainty of $\pm 25 \%$ of the tree-ring count" (Friedrich et al. 2006: 548). In the light of Cherubini et al's (2013) results, it is questionable whether the level of uncertainty proposed by Friedrich et al. is sufficient. Furthermore, their final official date of 1627 to 1600 BC unfortunately did not consider the uncertainties admitted in their own supporting material.

Further doubt has been cast on this dating because of its incompatibility with radiocarbon determinations from sites not subject to obvious reservoir and volcano effects. There are also the numerous interconnections between pottery and other archaeological finds identical to those found in the volcanic destruction stratum at Santorini and materials found at other sites dated to $c$. 1525-1490 BC (Warren 2010; Wiener 2010). Interconnections with the well-established Egyptian historical chronology are now confirmed by 211 radiocarbon measurements (Bietak \& Höflmayer 2007; Bronk Ramsey et al. 2010; Warren 2010; Wiener 2010). Finally, pumice chemically traced to the Minoan-period eruption of Santorini has been found at 15 sites in Egypt, the Near East, on Cyprus, the Anatolian coast and in the Aegean in contexts a century later than the dates proposed by Friedrich et al. Pumice from earlier contexts has in all cases been traced to earlier volcanic eruptions in the Dodecanese, and in one case to the Lipari volcano (Wiener 2010).

Friedrich et al. (2006) claimed that they have left a 50 per cent margin for error in counting the number of tree-rings, but if olive trees do not produce identifiable annual treerings, and no two laboratories can agree on the number of tree-rings observed (Cherubini et al. 2013), no secure dating is possible. In addition, there is no reason to assume that their sampled branch was necessarily alive when it was buried during the volcanic eruption. Olive trees in the Mediterranean frequently carry dead branches, sometimes very old ones.

\section{Conclusions}

The date of the Thera Minoan volcanic eruption is of major importance for understanding the relationships between the Late Bronze Age civilisations of Egypt, the Near East and the Aegean world. The contention that a charred olive tree branch was alive when buried in tephra during the Santorini eruption and had recognisable tree-rings allowed Friedrich et al. (2006) to date that eruption to 1627-1600 BC. If correct, this would have implied major changes in our understanding of developments in the Late Bronze Age civilisations of the Aegean and the eastern Mediterranean. Careful evaluation of their results is therefore of critical importance. Olive wood tree-rings are, however, very problematic in nature. A dendrochronological analysis of olive trees currently growing on Santorini (Cherubini et al. 2013) showed that it is impossible to determine the number of tree-rings. Accordingly, caution should be applied to the dating offered by Friedrich et al. and their proposal cannot 
be used to discount the date range of 1525-1490 BC proposed for the eruption from numerous other radiocarbon studies.

\section{Acknowledgements}

We thank the Institute for Aegean Prehistory (INSTAP) for partly funding the sampling work.

\section{References}

Arnan, X., B.C. López, J. Martínez-Vilalta, M. EsTORACH \& R. POYATOS. 2012. The age of monumental olive trees (Olea europaea) in northeastern Spain. Dendrochronologia 30: 11-14. http://dx.doi.org/10.1016/j.dendro.2011.02.002

Baillie, M.G.L. \& M.A.R. Munro. 1988. Irish tree rings, Santorini and volcanic dust veils. Nature 332: 344-46. http://dx.doi.org/10.1038/332344a0

Battipaglia, G., V. De Micco, W.A. Brand, P. Linke, G. Aronne, M. SAurer \& P. Cherubini. 2010. Variations of vessel diameter and $\delta^{13} \mathrm{C}$ in false rings of Arbutus unedo L. reflect different environmental conditions. New Phytologist 188: 1099-112.

BIETAK, M. \& F. HÖFLMAYER. 2007. Introduction: high and low chronology, in M. Bietak \& E. Czerny (ed.) The synchronisation of civilizations in the eastern Mediterranean in the second millenium B.C. III: Proceedings of the SCIEM $20002^{\text {nd }}$ EuroConference, Vienna, 28 May-1 June 2003: 13-23. Vienna: Austrian Academy of Sciences.

Bronk Ramsey, C., M.W. DeE, J.M. Rowland, T.F.G. Higham, S.A. Harris, F. Brock, A. Quiles, E.M. Wild, E.S. Marcus \& A.J. ShORTLAND. 2010. Radiocarbon-based chronology for dynastic Egypt. Science 328: 1554-57. http://dx.doi.org/10.1126/science.1189395

Carapezza, M.L., T. Ricci, M. Ranaldi \& L. TARCHINI. 2009. Active degassing structures of Stromboli and variations in diffuse $\mathrm{CO}_{2}$ output related to the volcanic activity. Journal of Volcanology and Geothermal Research 182: 231-45. http://dx.doi.org/10.1016/j.jvolgeores.2008.08.006

Cherubini, P., B.L. Gartner, R. Tognetti, O.U. BRÄKER, W. SCHOCH \& J.L. INNES. 2003. Identification, measurement and interpretation of tree-rings in woody species from Mediterranean climates. Biological Reviews 78: 119-48. http://dx.doi.org/10.1017/S1464793102006000

Cherubini, P., T. Humbel, H. Beeckman, H. Gärtner, D. Mannes, C. Pearson, W. Schoch, R. TognetTi \& S. Lev-Yadun. 2013. Olive tree-ring problematic dating: a comparative analysis. PloS ONE 8: e54730. http://dx.doi.org/10.1371/ journal.pone.0054730
De Micco, V., G. Battipaglia, W.A. Brand, P. Linke, M. Saurer, G. Aronne \& P. Cherubini. 2012.

Discrete versus continuous analysis of anatomical and $\delta^{13} \mathrm{C}$ variability in tree-rings with intra-annual-density-fluctuations. Trees 26: 513-24.

De Micco, V., G. Battipaglia, P. Cherubini \& G. ARONNE. In press. Comparing methods to analyse anatomical features of tree-rings with and without intra-annual density fluctuations (IADFs). Dendrochronologia.

Donders, T.H., M. Decuyper, S.E. Beaubien, T.B. van Hoof, P. Cherubini \& U. SaAs-KLaASSEN. 2013. Tree-rings as biosensor to detect leakage of subsurface fossil $\mathrm{CO}_{2}$. International Journal of Greenhouse Gas Control 19: 387-95. http://dx.doi.org/10.1016/j.ijggc.2013.09.017

Doumas, C. 2010. Akrotiri, in E.H. Cline (ed.) The Oxford handbook of the Bronze Age Aegean (ca. 3000-1000 BC): 752-61. Oxford: Oxford University Press.

Frezzotti, M.L., A. Peccerillo \& G. Panza. 2009. Carbonate metasomatism and $\mathrm{CO}_{2}$ lithosphere-asthenosphere degassing beneath the western Mediterranean: an integrated model arising from petrological and geophysical data. Chemical Geology 262: 108-20. http://dx.doi.org/10.1016/j.chemgeo.2009.02.015

Friedrich, W.L. \& J. HeInemeIER. 2009. The Minoan eruption of Santorini radiocarbon dated to $1613 \pm 13$ BC-geological and stratigraphic considerations, in D.A. Warburton (ed.) Time's up! Dating the Minoan eruption of Santorini: Acts of the Minoan Eruption Chronology Workshop, Sandbjerg, November 2007 (Monographs of the Danish Institute at Athens 10): 56-63. Athens: Danish Institute at Athens.

Friedrich, W.L., B. Kromer, M. Friedrich, J. Heinemeier, T. Pfeiffer \& S. Talamo. 2006. Santorini eruption radiocarbon dated to 1627-1600 B.C. Science 312: 548. http://dx.doi.org/10.1126/science. 1125087

(C) Antiquity Publications Ltd. 
-2009 . Santorini eruption radiocarbon dated to 1627-1600 BC: further discussion, in S.W. Manning \& M.J. Bruce (ed.) Tree-rings, kings, and Old World archaeology and environment: papers presented in honor of Peter Ian Kuniholm: 293-98. Oxford \& Oakville (CT): Oxbow.

Heinemeier, J., W.L. Friedrich, B. Kromer \& C. Bronk Ramsey. 2009. The Minoan eruption of Santorini radiocarbon dated, in D.A. Warburton (ed.) Time's up! Dating the Minoan eruption of Santorini: Acts of the Minoan Eruption Chronology Workshop, Sandbjerg, November 2007 (Monographs of the Danish Institute at Athens 10): 285-93. Athens: Danish Institute at Athens.

LaMarche, V.C. \& K.K. HirschbOeCK. 1984. Frost rings in trees as records of major volcanic eruptions. Nature 307: 121-26. http://dx.doi.org/10.1038/307121a0

Manning, S.W., C. Bronk Ramsey, W. Kutschera, T. Higham, B. Kromer, P. Steier \& E.M. Wild. 2006. Chronology for the Aegean Late Bronze Age 1700-1400 B.C. Science 312: 565-69. http://dx.doi.org/ 10.1126/science. 1125682

-2009. Dating the Santorini/Thera eruption by radiocarbon: further discussion (AD 2006-2007), in S.W. Manning \& M.J. Bruce (ed.) Tree-rings, kings, and Old World archaeology and environment: papers presented in honor of Peter Ian Kuniholm: 299-316. Oxford \& Oakville (CT): Oxbow.

Pearson, C.L., D.S. Dale, P.W. Brewer, P.I. Kuniholm, J. Lipton \& S.W. MAnning. 2009. Dendrochemical analysis of a tree-ring growth anomaly associated with the Late Bronze Age eruption of Thera. Journal of Archaeological Science 36: $1206-14$. http://dx.doi.org/10.1016/j.jas.2009.01.009

Rossi, L., L. Sebastiani, R. TognetTi, R. D'Andria, G. Morelli \& P. Cherubini. 2013. Tree-ring wood anatomy and stable isotopes show structural and functional adjustments in olive trees under different water availability. Plant Soil 372: 567-79. http://dx.doi.org/10.1007/s11104-013-1759-0
Saurer, M., P. Cherubini, G. Bonani \& R. SiegWolf. 2003. Tracing carbon uptake from a natural $\mathrm{CO}_{2}$ spring into tree rings: an isotope approach. Tree Physiology 23: 997-1004.

WARREN, P.M. 2006. The date of the Thera eruption in relation to Aegean-Egyptian interconnections and the Egyptian historical chronology, in E. Czerny, I. Hein, H. Hunger, D. Melman \& A. Schwab (ed.) Timelines: studies in honour of Manfred Bietak (Orientalia Lovaniensia Analecta 149): 305-21. Leuven: Peeters.

- 2009. The date of the Late Bronze Age eruption of Santorini, in D.A. Warburton (ed.) Time's up! Dating the Minoan eruption of Santorini: Acts of the Minoan Eruption Chronology Workshop, Sandbjerg, November 2007 (Monographs of the Danish Institute at Athens 10): 181-86. Athens: Danish Institute at Athens.

- 2010. The absolute chronology of the Aegean circa 2000 B.C. -1400 B.C. A summary, in W. Müller (ed.) Corpus der minoischen und mykenischen Siegel. Beiheft 8: Die Bedeutung der minoischen und mykenischen Glyptik: 383-94. Mainz: von Zabern.

WIENER, M.H. 2009a. Cold fusion: the uneasy alliance of history and science, in S.W. Manning \& M.J. Bruce (ed.) Tree-rings, kings, and Old World archaeology and environment: papers presented in honor of Peter Ian Kuniholm: 277-92. Oxford \& Oakville (CT): Oxbow.

$-2009 \mathrm{~b}$. The state of the debate about the date of the Theran eruption, in D.A. Warburton (ed.) Time's up! Dating the Minoan eruption of Santorini: Acts of the Minoan Eruption Chronology Workshop, Sandbjerg, November 2007 (Monographs of the Danish Institute at Athens 10): 197-206. Athens: Danish Institute at Athens.

- 2010. A point in time, in O. Krzyszkowska (ed.) Cretan offerings: studies in honour of Peter Warren: 367-94. London: British School at Athens. 


\title{
The olive branch chronology stands irrespective of tree-ring counting
}

\author{
Walter L. Friedrich ${ }^{1}$, Bernd Kromer $^{2}$, Michael Friedrich ${ }^{2,3}$, \\ Jan Heinemeier ${ }^{4}$, Tom Pfeiffer ${ }^{5} \&$ Sahra Talamo $^{6}$
}

Cherubini et al. (above) question the reliability of identifying annual growth increments in olive trees, and therefore voice caution against the result of the wiggle-match of the four sections of a branch of an olive tree to the ${ }^{14} \mathrm{C}$ calibration curve. Friedrich et al. (2006) were well aware of the problematic density structure of olive trees, and therefore assigned rather wide error margins of up to 50 per cent to the ring count. This still resulted in a late seventeenth century $\mathrm{BC}$ youngest date for the modelled age range of the outermost section of wood (95.4\% probability). One can even remove any constraint from ring counting altogether and model the four radial sections as a simple ordered sequence, in which only the relative position is used as prior information, in other words that outer sections are younger than inner ones in a radial section. The model

Sequence()

\{

Boundary(“S”);

R_Date(“innermost section”, 3383, 11);

R_Date(“2nd section”, 3372, 12); R_Date(“3rd section”, 3349, 12); R_Date(“outermost section”, 3331, 10); Boundary(“E”);

\} ;

yields $1609 \mathrm{cal} \mathrm{BC}(95.4 \%)$ as the minimum age of the outermost section (IntCal13; Reimer et al. 2013). The $95.4 \%$ range is $1656-1609$ cal BC (modelled using OxCal v.4.2 (Bronk Ramsey 2009)).

Secondly, Cherubini et al. essentially limit their discussion of the dispute between the historical Egyptian chronology and natural scientific dating methods to the literature published only to the year 2010, and ignore important subsequent contributions. For instance Höflmayer (2012: 444) concludes that "Theran pumice in eastern Mediterranean contexts and White Slip pottery on Thera and in the Levant have been found to be inconclusive", because of an unknown interval between eruption (pumice)/production (ceramics) and deposition; hence this evidence must be considered a terminus ante quem.

\footnotetext{
${ }^{1}$ Department of Geoscience, Aarhus University, Hoegh Guldbergsgade 2, DK-8000 Aarhus, Denmark

${ }^{2}$ University of Heidelberg, Institute of Environmental Physics, Im Neuenheimer Feld 229, D-69120 Heidelberg, Germany

${ }^{3}$ Institute of Botany, Hohenheim University, D-70593 Stuttgart, Germany

${ }^{4}$ Accelerator Mass Spectrometry ${ }^{14} \mathrm{C}$ Dating Centre, Department of Physics and Astronomy, Aarhus University, DK-8000 Aarhus C, Denmark

${ }^{5}$ VolcanoDiscovery, Kronenstrasse 2, Troisdorf 53840, Germany

${ }^{6}$ Max Planck Institute for Evolutionary Anthropology, Department of Human Evolution, Deutscher Platz 6, D-04103 Leipzig, Germany
}

(C) Antiquity Publications Ltd. 

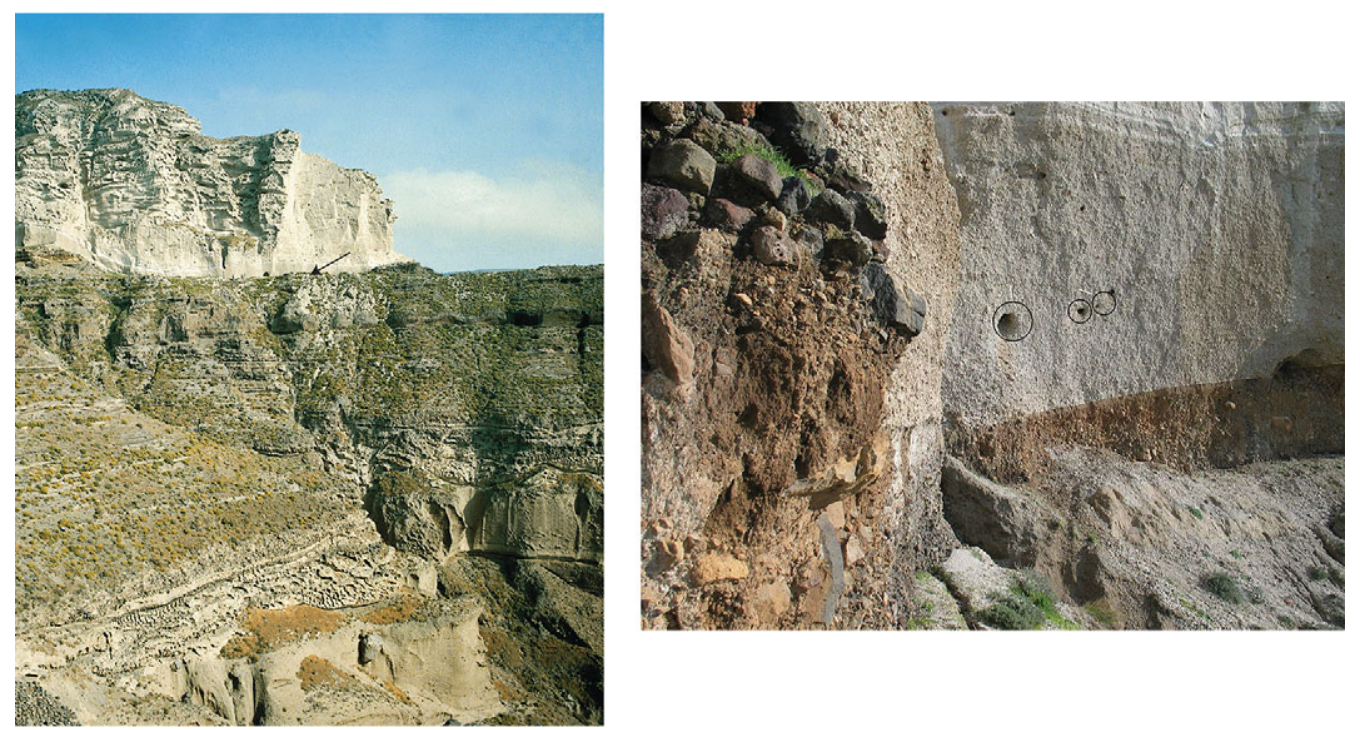

Figure 1. Left): the site (172m asl, marked by an arrow) where two olive trees were buried alive still in living position in the pumice of the Minoan eruption; right) a close-up of the site with a Bronze Age wall visible (upper left). The circles mark the place where branches of the first olive tree were found.

Kutschera et al. (2012) find a similar offset of about a century between a stratified series of ${ }^{14} \mathrm{C}$ dates from Tell el-Dab'a and the archaeological dating of the site's sequence, far away from any potential $\mathrm{CO}_{2}$ of volcanic origin. They observe that the generally good agreement between ${ }^{14} \mathrm{C}$ dating and the Egyptian historical chronology (Bronk Ramsey et al. 2010) cannot be quoted here, because the eighteenth and seventeenth centuries are not covered in that model (Kutschera et al. 2012: fig. 7). Manning and Kromer (2012) present an extensive discussion of the statistical robustness of the set of single year samples from the Akrotiri volcanic destruction level, contrary to the statement of Cherubini et al. claiming 'wide disparities in the underlying measurements', and they discuss the potential effect of small volcanic $\mathrm{CO}_{2}$ contributions to the samples used in the data sets, as proposed by Soter (2011). They find that even allowing for a subjective selection of a 'low-date clump' the 'likely date for the Santorini volcanic eruption horizon lies, in round terms, in the last three decades of the seventeenth century BC'. Cherubini et al. refer to a 'date range for the eruption of 1525-1490 BC proposed by numerous other radiocarbon studies' (our italics), but these studies simply do not exist. There is instead a robust body of ${ }^{14} \mathrm{C}$ dates based on reliable sample material and secure contexts which favours the late seventeenth century $\mathrm{BC}$ and does not run beyond $1520 \mathrm{cal}$ BC.

Hence while we agree with Cherubini et al. that caution is justified with respect to annual ring counting of olive trees, we can nevertheless show that simply assuming a growth pattern sequential in time, without any reference to ring counting, still constrains the date of the eruption to the late seventeenth century BC. Cherubini et al. postulate that the olive branch could have been dead or polluted by old $\mathrm{CO}_{2}$. These arguments too can be ruled out by the following observations. The fact that the age of the outermost olive section agrees well with the ages of the short-lived samples from Akrotiri renders it extremely implausible that

(C) Antiquity Publications Ltd. 


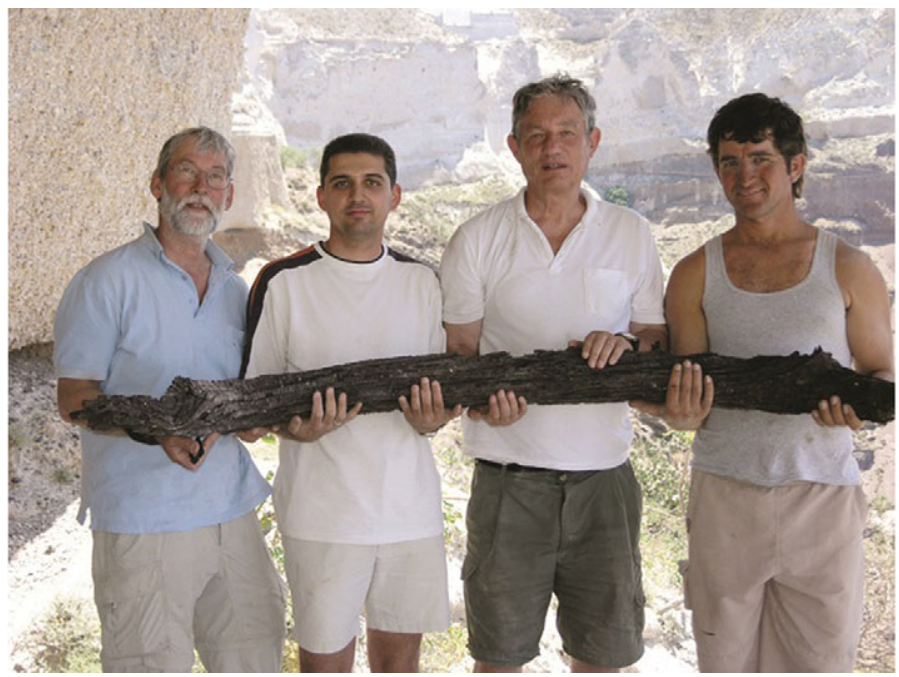

Figure 2. A stem of an olive tree excavated only $9 \mathrm{~m}$ away from the olive tree used for the dating.

the olive branch had been dead for a substantial number of years prior to the time of the eruption. Furthermore the olive tree and a second one next to it were found in the pumice in living position (Figures $1 \& 2$ ), and under each tree, olive leaves were found testifying that the trees were still alive when buried (Pfeiffer 2003; Friedrich 2009).

The unique role of the ${ }^{14} \mathrm{C}$ sequence obtained from the olive branch in the chronology dispute is that the strength of the Bayesian approach (combining prior information with ${ }^{14} \mathrm{C}$ dates) allows the ambiguity of the ${ }^{14} \mathrm{C}$ calibration of single dates, leading to a low but statistically relevant probability in the sixteenth century even at highest precision, to be resolved. At the same time, Cherubini et al. ignore important progress in the discussion about the Santorini eruption in recent years, which negates various of their other statements.

\section{References}

BRONK RAMSEY, C. 2009. Bayesian analysis of radiocarbon dates. Radiocarbon 51: 337-60.

Bronk Ramsey, C., M.W. DeE, J.M. Rowland, T.F.G. Higham, S.A. Harris, F. Brock, A. Quiles, E.M. Wild, E.S. Marcus \& A.J. SHORTLAND. 2010. Radiocarbon-based chronology for Dynastic Egypt. Science 328: 1554-57.

http://dx.doi.org/10.1126/science.1189395

FRIEDRICH, W.L. 2009. Santorini: volcano, natural history, mythology. Aarhus: Aarhus University Press.

Friedrich, W.L., B. Kromer, M. Friedrich, J. Heinemeier, T. Pfeiffer \& S. Talamo. 2006. Santorini eruption radiocarbon dated to 1627-1600 B.C. Science 312: 548. http://dx.doi.org/10.1126/science.1125087

HÖflMaYer, F. 2012. The date of the Minoan Santorini eruption: quantifying the "offset". Radiocarbon 54: 435-48. http://dx.doi.org/10.2458/azu_js_rc. v54i3-4.16157

(C) Antiquity Publications Ltd.
Kutschera, W., M. BietaK, E.M. Wild, C. Bronk Ramsey, M. Dee, R. Golser, K. Kopetzky, P. STADler, P. Steier, U. Thanheiser \& F. WENINGER. 2012. The chronology of Tell el-Daba: a crucial meeting point of ${ }^{14} \mathrm{C}$ dating, archaeology, and Egyptology in the $2^{\text {nd }}$ millennium BC. Radiocarbon 54: 407-22.

http://dx.doi.org/10.2458/azu_js_rc.v54i3-4.16187

Manning, S.W. \& B. Kromer. 2012. Considerations of the scale of radiocarbon offsets in the east Mediterranean, and considering a case for the latest (most recent) likely date for the Santorini eruption. Radiocarbon 54: 449-74.

http://dx.doi.org/10.2458/azu_js_rc.v54i3-4.16169

Pfeiffer, T. 2003. Two catastrophic volcanic eruptions in the Mediterranean: Santorini 1645 B.C. and Vesuvius 79 A.D. Unpublished PhD dissertation, Aarhus University. 
Reimer, P.J., E. Bard, A. Bayliss, J.W. Beck, P.G. Blackwell, C. Bronk Ramsey, C.E. Buck, H. CHENG, R.L. EDWARDS, M. FREIDRICH, P.M. Grootes, T.P. Guilderson, H. Haflidason, I. Hajdas, C. Hatté, T.J. Heaton, D.L. Hoffmann, A.G. HogG, K.A. HugHen, K.F. KAISER, B. Kromer, S.W. Manning, M. NiU, R.W. Reimer, D.A. RICHARDS, E.M. SCOTT, J.R. SOUTHON, R.A. Staff, C.S.M. Turney \& J. van Der Plicht. 2013. IntCal13 and Marine13 radiocarbon age calibration curves $0-50,000$ years cal BP. Radiocarbon 55: 1869-87. http://dx.doi.org/10.2458/azu_js_rc. 55.16947
SoteR, S. 2011. Radiocarbon anomalies from old $\mathrm{CO}_{2}$ in the soil and canopy air. Radiocarbon 53: 55-59.

\title{
Radiocarbon and the date of the Thera eruption
}

\author{
Manfred Bietak*
}

The criticism of the date of the olive tree branch from Thera offered by Cherubini $e t$ al. (above) has to be fully supported. The attribution of the branch in question to the late part of the seventeenth century $\mathrm{BC}$ is by itself not unexpected, as most of the other radiocarbon dates of short-lived samples from the site of Akrotiri fall into the second half of that century. The attempt to produce a wiggle-match drawn from a succession of non-existent tree-rings in this branch, and to fit such a result into the general calibration curve to give the illusion of precision, however, does not pass the scientific test. Olive trees do not develop annual tree-rings. Furthermore, no proof could be produced that this branch was alive during the eruption. The olive leaves found in an underlying horizon had no connection to the branch and could have been preserved in dry ground like this for ages before the eruption occurred. The remains of the branch were not found in a tight-fitting context but in a much larger cavity and it seems that the outer part of the branch, including the bark edge (waney edge) — contrary to the assertions of Friedrich et al. (2006)—are missing. The other issue in this scientific discussion is that dating the Thera eruption by ${ }^{14} \mathrm{C}$ is much more problematic than is acknowledged by scientists, since it clashes distinctly with historical and archaeological dating.

There are periods and regions where ${ }^{14} \mathrm{C}$ dates can be accommodated within the historical chronology. A success story in this respect seems to be the Oxford laboratory study (Bronk Ramsey et al. 2010) which from historically well-dated samples, with the help of sophisticated Bayesian statistics (incorporating successions of reigns of kings and reign lengths), produced dates which could be harmonised with the Egyptian historical chronology. Most of the samples came from arid regions in Upper and Middle Egypt. It is difficult to know if the papyrus samples came from plants of the northern or southern Delta, the Fayum or

\footnotetext{
*Austrian Academy of Sciences, Dr. Ignaz Seipel-Platz, A-1010 Vienna, Austria
}

(C) Antiquity Publications Ltd. 

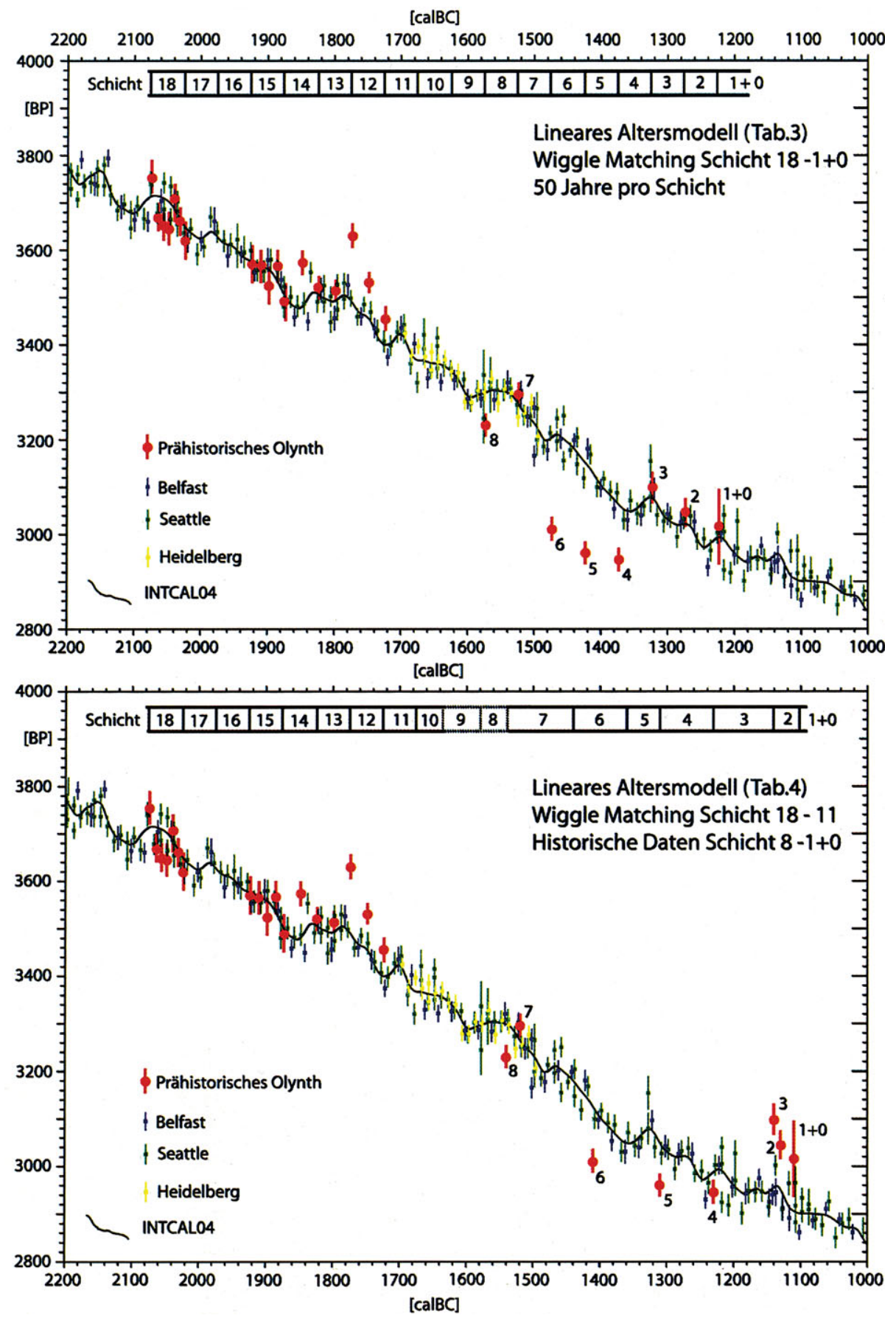

Figure 1. Sequence of Early to Late Helladic series at Hagios Mamas (after Hänsel et al. 2010: fig. 15).

(c) Antiquity Publications Ltd. 


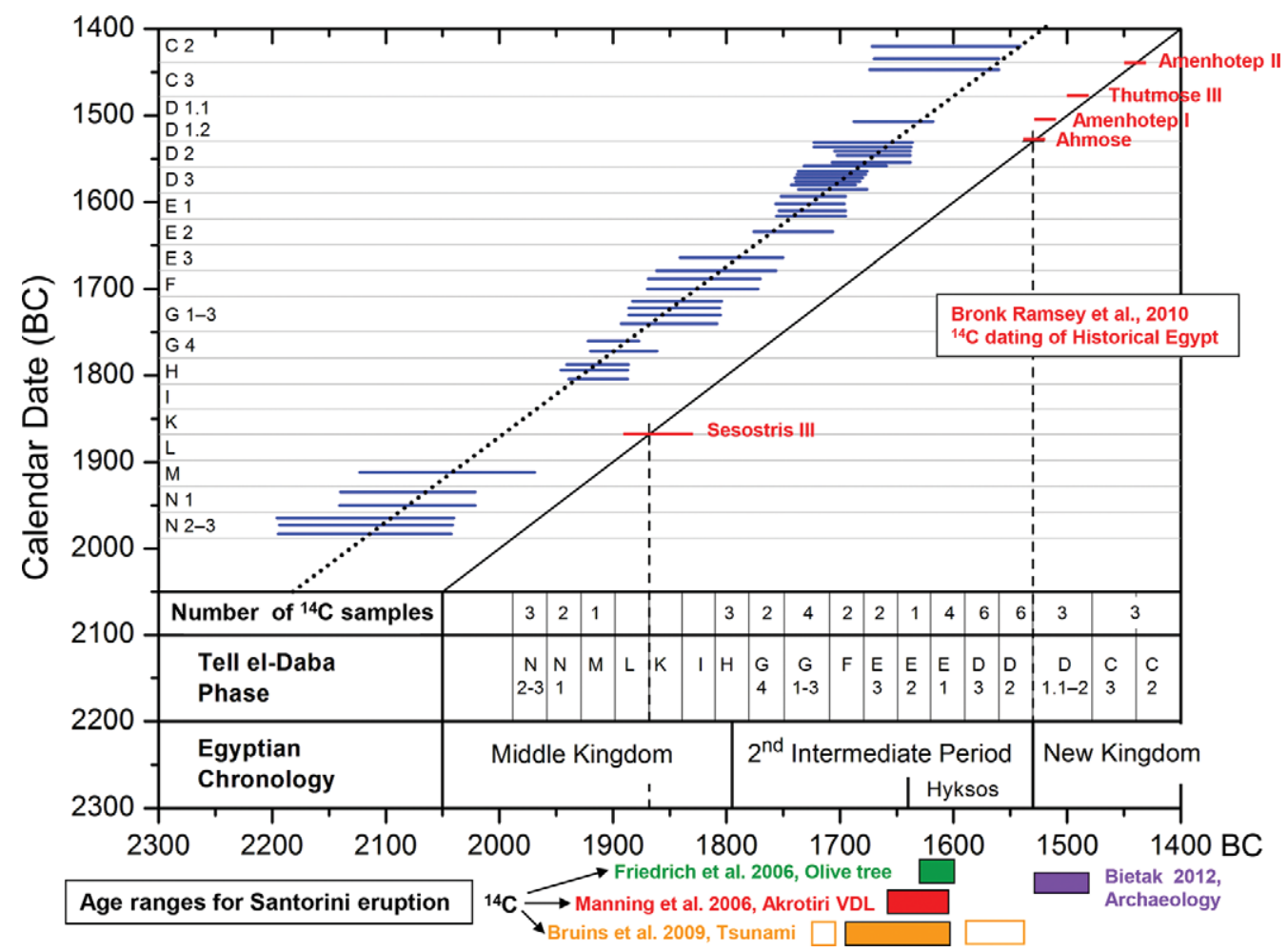

Figure 2. Offsets of the Tell el-Dab'a series of radiocarbon dates (after Kutschera et al. 2012: fig. 7).

Upper Egypt. There are, however, also periods and regions where one could recognise serious offsets. The region with distinct offsets and the possibility of comparing ${ }^{14} \mathrm{C}$ results with the historical chronology is the eastern Mediterranean, not only the Aegean or the island of Thera, but also northern Egypt and to some extent the Levant.

The stratigraphic series at Hagios Mamas in Macedonia, covering over a millennium (Hänsel $e t$ al. 2010), shows very clearly that besides the wiggles of the calibration curve, ${ }^{14} \mathrm{C}$ dates do not produce chronometrically consistent results. In this case there are two series of outliers within an otherwise acceptable result (Figure 1). A stratigraphic series at Tell el-Dab'a (ancient Avaris and Peru-nefer) covering the period from the beginning of the Twelfth Dynasty to the reign of Amenhotep II (c. 2000-1400 BC) has over 40 samples showing continuous offsets giving dates 100 to 120 years too high throughout this period (Kutschera et al. 2012) (Figure 2). The stratigraphic series is fixed near its lower end (Phase K) by a stela of the fifth year of Senwosret III (c.1889 BC; chronology after Schneider 2008), subsequently by seal impressions of the Hyksos Khayan (c.1600 BC) and the conquest of Avaris under king Ahmose (c. $1530 \mathrm{BC}$ ) and at its upper end by scarabs of Thutmose III (c. 1479-1425 BC) and Amenhotep II (c. 1425-1400 BC). There are also cross-dates to other sites which fit in perfectly (Bietak 2013). Senwosret III, Khayan, Thutmose III and Amenhotep II could not have reigned more than 100 years earlier than the historical chronology maintains, and Avaris could not have been conquered over 100 years earlier. Hence it is evident that there is a systematic offset within this series.

(C) Antiquity Publications Ltd. 


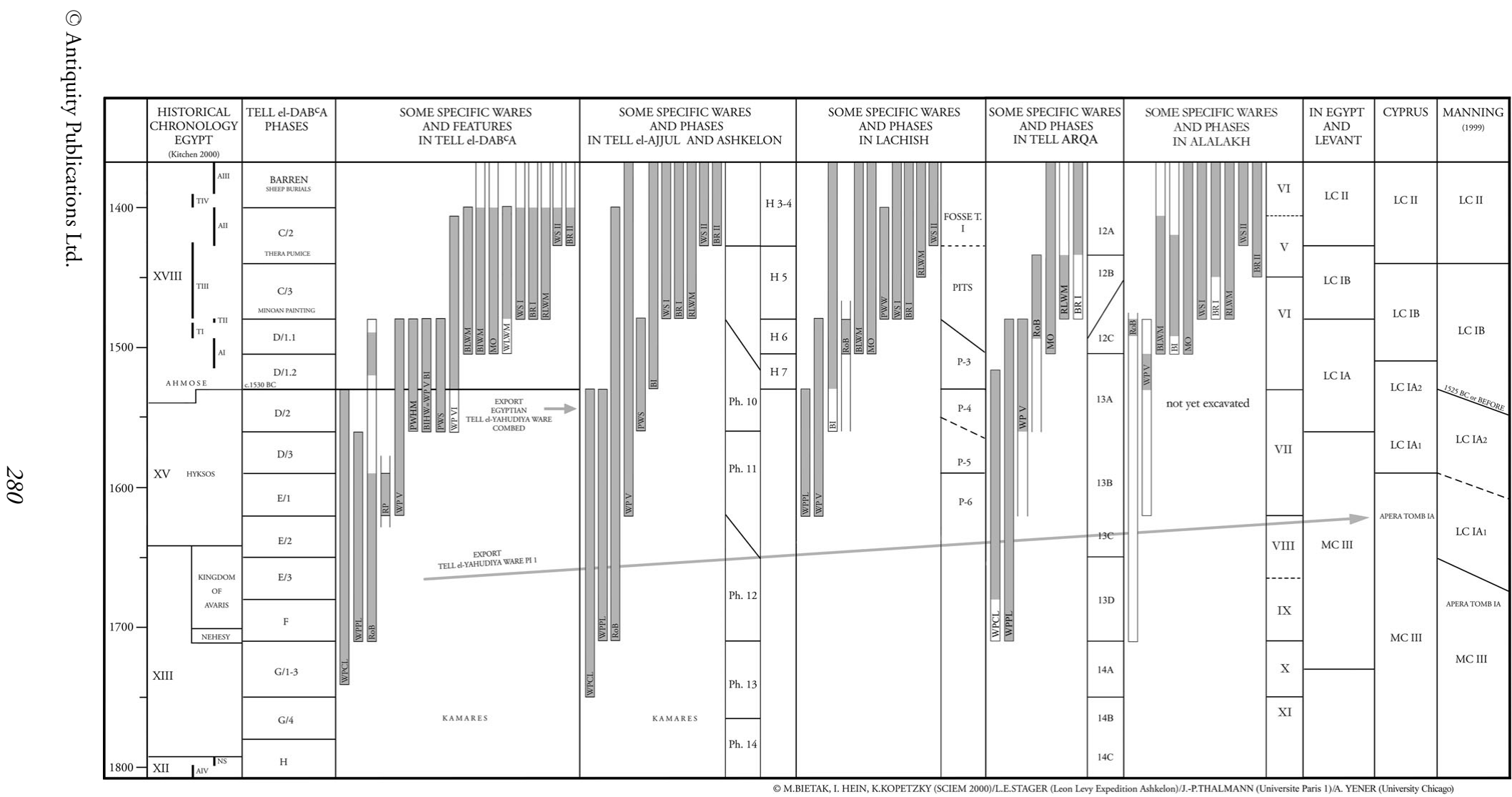

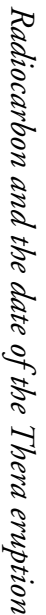

Figure 3. Stratigraphie comparée, showing the first appearances and the time-spans of specific ceramic families in a site-to-site comparison (after Bietak 2013: fig. 8; (C) M. Bietak, K. Kopetzky, I. Hein, L. Stager, J.-P. Thalman \& A. Yener). 
The Aegean shows similar offsets during the late Middle and the early Late Bronze Age. Proof can be found in the circulation of different Late Cypriot wares which have their first appearance in the same chronological stages in Cyprus, Egypt and the Levant (Figure 3). Special mention must be made of the so-called White Slip I Ware which turns up for the first time in Egypt and the Levant several decades after the beginning of the New Kingdom. It is also present (in the form of a bowl repaired in antiquity) in a pre-eruption context on Thera. Sturt Manning's claim (1999: 35, 150-91) that this bowl was produced in northern Cyprus 150 years before White Slip I Ware appears in southern Cyprus and finally in Egypt can be ruled out completely. There is no evidence that the Cypriot Late Bronze Age started in northern Cyprus with the same succession of Late Cypriot Wares 150 years before the rest of the island and the Levant (Bietak 2004). There is also no proof that this bowl was produced in northern Cyprus. Furthermore, the north of the island was in contact with Egypt, as can be shown by Egyptian-made Tell el-Yahudiya Ware found in northern Cyprus and White Painted V-Ware from northern Cyprus found at Tell el-Dab'a (Bietak 2013: 89-90). Egyptian-made Tell el-Yahudiya Ware appeared on Cyprus only very slightly later than in Egypt.

Another strong argument for the low Aegean chronology was presented by the investigation of over 400 samples of pumice from well-stratified contexts in Egypt and the Levant (Sterba et al. 2009). Not a single sample was found before the Thutmosid period in Egypt or the beginning of the Late Bronze Age in the Levant. They appear suddenly and in large quantities from $c .1500 \mathrm{BC}$ onwards. No pumice from the Minoan eruption at Thera was found in Middle Bronze Age contexts, which instead used resources of very different origin.

At the moment it is not possible to offer an explanation for this very distinct offset, which seems to appear close to the Mediterranean Sea. A solution to the riddle requires focused research on all possible old carbon effects from the sea on the vegetation around its shores. Major corrections of the historical chronology of Egypt and its synchronisation with the Eastern Mediterranean world can be ruled out.

There are at present trends by different scholars (Felix Höflmayer, Sturt Manning) to use maximal dates for some kings of the Eighteenth Dynasty such as Thutmose II, Amenhotep II and Thutmose IV in order to stretch the beginning of the New Kingdom back to nearly $1580 \mathrm{BC}$ while at the same time trying to bring down the radiocarbon chronology of the Minoan eruption to shortly before $1600 \mathrm{BC}$. They overlook the fact that from a statistical point of view calculation by adding up only maximal possible but unproven reign lengths leads to unfeasible results, especially as one has to claim among the officials of the first half of the Eighteenth Dynasty serving under several kings abnormally high ages - a very unlikely solution. Such historical constructions are only attempted under stress from the radiocarbon results which may themselves have to be corrected. Therefore this is a methodologically highly doubtful and unreliable procedure which still leaves a gap of c. 30-60 or more years between historical dating and the result of carbon chronology in the Aegean, while the Oxford radiocarbon chronology with Bayesian statistics endorsed the traditional New Kingdom chronology (start of the reign of Thutmose at 1479 BC). This alone shows that there is a difference in the treatment of historical and scientific data by different research groups which leads to contradictory results. 


\title{
Acknowledgements
}

I would like to thank Otto Cichocki of the Dendro Laboratory of the Vienna Institute of Archaeological Science for his assessment of the matter of the absence of the outer part of the branch (the bark edge).

\section{References}

BIETAK, M. 2004. [Review of $A$ test of time by Sturt W. Manning]. Bibliotheca Orientalis 61: 199-222.

-2013 . Antagonisms in historical and radiocarbon chronology, in A.J. Shortland \& C. Bronk Ramsey (ed.) Radiocarbon and the chronologies of Ancient Egypt: 78-110. Oxford: Oxbow.

Bronk Ramsey, C., M.W. DeE, J.M. Rowland, T.F.G. Higham, S.A. Harris, F. Brock, A. Quiles, E.M. Wild, E.S. Marcus \& A.J. ShortLand. 2010. Radiocarbon-based chronology for Dynastic Egypt. Science 328: 1554-57. http://dx.doi.org/10.1126/ science. 1189395

Friedrich, W.L., B. Kromer, M. Friedrich, J. Heinemeier, T. Pfeiffer \& S. Talamo. 2006. Santorini eruption radiocarbon dated to 1627-1600 B.C. Science 312: 548. http://dx.doi. org/10.1126/science. 1125087

HÄNsel, B., B. Horejs, R. Jung \& B. Weninger. 2010. Die absolute Chronologie der Schichten des prähistorischen Olynth, in B. Hänsel \& I. Aslanis (ed.) Das Prähistorische Olynth, Ausgrabungen in der Toumba Agios Mamas 1994-1996, Die Grabung und der Baubefund (Prähistorische Archäologie in Südosteuropa 23): 301-81. Rahden: Marie Leidorf.
Kutschera, W., M. BietaK, E.M. Wild, C. Bronk Ramsey, M. Dee, R. Golser, K. Kopetzky, P. Stadler, P. Steirer, U. ThanheISER \& F. WENINGER 2012. The chronology of Tell el-Dab'a: a crucial meeting point of ${ }^{14} \mathrm{C}$ dating, archaeology and Egyptology in the $2^{\text {nd }}$ millennium BC. Radiocarbon 54: 407-22. http://dx.doi.org/ 10.2458/azu_js_rc.v54i3-4.16169

Manning, S.W. 1999. A test of time: the volcano of Thera and the chronology and history of the Aegean and East Mediterranean in the mid second millennium BC. Oxford: Oxbow

SCHNEIDER, T. 2008. Das Ende der Kurzen Chronologie: Eine Kritische Bilanz der Debatte zur absoluten Datierung des Mittleren Reiches und der Zweiten Zwischenzeit. Ä\&L 18: 275-313.

Sterba, J.H., K.P. Foster, G. Steinhauser \& $\mathrm{M}$. BICHLER. 2009. New light on old pumice: the origins of Mediterranean volcanic material from ancient Egypt. Journal of Archaeological Science 36: 1738-44. http://dx.doi.org/10.1016/j.jas. 2009.03.031

\section{The Thera olive branch, Akrotiri (Thera) and Palaikastro (Crete):} comparing radiocarbon results of the Santorini eruption

\author{
Hendrik J. Bruins ${ }^{1} \&$ Johannes van der Plicht ${ }^{2,3}$
}

An olive branch is traditionally a symbol of peace, but not necessarily in the context of chronological problems in the Eastern Mediterranean region and the Near East during the second millennium BC. Cherubini et al. (above) strongly attack the radiocarbon dating

\footnotetext{
${ }^{1}$ Jacob Blaustein Institutes for Desert Research, Ben-Gurion University of the Negev, Sede Boqer Campus, 84990, Israel(Email: hjbruins@bgu.ac.il)

${ }^{2}$ Centre for Isotope Research, University of Groningen, Nijenborgh 4, 9747 AG, Groningen, The Netherlands

${ }^{3}$ Faculty of Archaeology, Leiden University, Reuvensplaats 3, 2311 BE, Leiden, The Netherlands
}

(C) Antiquity Publications Ltd. 
by Friedrich et al. (2006) of an ancient olive branch, buried by volcanic tephra during the Minoan Santorini eruption. The criticism stems from their investigation of growth rings in modern olive trees on Santorini. The authors attempt with additional arguments, beyond their botanical investigation, to defend the traditional low chronology of the Santorini eruption of around 1500 BC. However, they ignore other crucial publications with radiocarbon dates concerning the Santorini eruption. In this response, we evaluate and negate their main arguments, and present our own conclusions.

\section{Olive tree growth rings}

Cherubini et al. suggest that the ancient olive branch found on Santorini, buried in volcanic tephra (Friedrich et al. 2006; Friedrich \& Heinemeier 2009), may have been a dead branch, whose outer rings were formed before the Minoan eruption. The authors give a very negative judgment concerning the potential identification of growth rings in olive trees, based on their research on modern trees in Santorini. Intra-annual wood density fluctuations are the principal problem according to the authors. Their article gives the strong impression that research involving the use of annual growth rings in olive trees is inherently hopeless.

Have other researchers in the Mediterranean region managed to carry out successful research on olive trees involving annual growth rings? The answer is yes. Despite the difficulty in distinguishing annual tree-rings in old, monumental olive trees, Arnan et al. (2012) were able to assess the age of sampled olive trees in Spain by counting the number of annual growth rings. The maximum estimated age (627士110 years) by Arnan $e t$ al. (2012) is among the highest reported for olive trees in the world. Terral and Durand (2006) investigated 446 samples of modern olive wood and 240 samples of ancient charcoal from olive trees in France and Spain. The authors succeeded in distinguishing tree-ring properties of irrigated olive trees from those cultivated under dry conditions (rainfall only). Rossi et al. (2013), successfully used dendrochronological data in modern olive trees from Italy, showing that cross-dating and synchronisation of ring-width time series is possible. Interestingly, Cherubini is one of the co-authors of that article. Yet, he writes above that: "identification of olive wood tree-rings from Santorini was found to be practically impossible". How can growth ring research on modern Italian olive trees be very successful, but not on modern Santorini olive trees?

\section{Volcanic 'dead' carbon photosynthesised by Santorini vegetation?}

The authors also suggest that no radiocarbon dating of material from the Santorini islands can be trusted as reliable. The assumption is that the atmosphere of Santorini contains 'dead' $\mathrm{CO}_{2}$ from the volcano, deficient in ${ }^{14} \mathrm{C}$. A local reservoir effect is supposed to be present that would make all radiocarbon dates from Santorini older by a century or more than the true calendrical dates. This line of reasoning is often expressed by those who question the high radiocarbon chronology for the Minoan eruption and Cherubini et al. (above) recycle these thoughts in their article.

The present is the key to the past, and it is clear that the Santorini volcano is usually silent. It is a totally different type of volcano to Stromboli on Sicily that is cited in their article.

(C) Antiquity Publications Ltd. 
Only minor degassing has occurred at the Santorini volcano during recent decades. The same situation probably prevailed during the time the olive tree and its branch (Friedrich et al. 2006; Friedrich \& Heinemeier 2009) were growing on Thera before the Minoan eruption.

In fact, we have clear evidence that the suggested 'dead' carbon effect in Santorini vegetation is not valid. Our ${ }^{14} \mathrm{C}$ dating of the Minoan eruption in tsunami deposits containing volcanic ash at the archaeological site of Palaikastro in north-eastern Crete (Bruins et al. 2008, 2009) gives the same results on short-lived organic material as those obtained for Akrotiri on Santorini. The distance of Palaikastro from the Santorini volcano is $155 \mathrm{~km}$. It is obvious that the atmosphere on Crete was not influenced by gases from the Santorini volcano prior to the eruption.

The uncalibrated original ${ }^{14} \mathrm{C}$ dates in radiocarbon years $\mathrm{BP}$ constitute the basis for comparison. The average ${ }^{14} \mathrm{C}$ age for the Minoan eruption, based on short-lived organic material from the archaeological excavations at Akrotiri on Thera, is 3350 10 BP (Bronk Ramsey et al. 2004). We published five radiocarbon dates from Palaikastro (Crete) on short-lived animal bones in tsunami layers related to the Minoan Santorini eruption (Bruins et al. 2008, 2009). Two radiocarbon dates are from a building destroyed by the tsunami at the Promontory coast at Palaikastro, and gave an average radiocarbon date of $3350 \pm 25 \mathrm{BP}$ (Bruins et al. 2008). Three other radiocarbon dates are from the main excavation area at Palaikastro, a few hundred metres away from the coast, near Building 6 , giving an average date of $3352 \pm 23$ BP (Bruins et al. 2009). These average ages from Crete are astoundingly similar to the average date of $3350 \pm 10$ BP for Akrotiri on Santorini (Bronk Ramsey et al. 2004). The conclusion must be that the ${ }^{14} \mathrm{C}$ dating results for the Minoan Santorini eruption from both Akrotiri (Thera) and Palaikastro (Crete) are identical. Hence there is no measurable volcanic reservoir effect on Santorini, as compared to Crete. The oft-invoked 'dead' volcanic carbon effect on the vegetation of Santorini is not an issue.

\section{Connections with Tell el-Dab'a and Egypt}

Cherubini et al. suggest that archaeological correlations, radiocarbon measurements and pumice from the Minoan Santorini eruption show "interconnections with well-established Egyptian historical chronology... in contexts a century later to the dates proposed by Friedrich et al. (2006)". We do not agree with this statement. Radiocarbon dates (Bietak \& Höflmayer 2007: 15; Kutschera et al. 2012: 410) for stratigraphic layer C/2 at Tell el-Dab'a, in which pumice from the Minoan eruption has been found, correlate in fact with the radiocarbon age of the eruption, as shown by Bruins (2010). Indeed the calibrated radiocarbon dates of Tell el-Dab'a are systematically older by more than 100 years than the archaeological age assessments, as discussed by Bruins (2010) and Kutschera et al. (2012).

\section{Radiocarbon dates for the Thera olive branch in relation to ${ }^{14} \mathrm{C}$ dates from Akrotiri (Thera) and Palaikastro (Crete)}

Whether the individual growth rings of the Thera olive branch have been correctly distinguished or not, we cannot decide. We can, however, compare the four individual (C) Antiquity Publications Ltd. 
Table 1. Radiocarbon dates (non-calibrated) of organic material related to layers associated with the Minoan Santorini eruption on Thera (Santorini) and tsunami (volcanic ash) layers at Palaikastro (Crete).

\begin{tabular}{|c|c|c|c|}
\hline Location & Material dated & ${ }^{14} \mathrm{C}$ date (yr BP) & Lab number \\
\hline \multicolumn{4}{|l|}{ Thera olive } \\
\hline \multirow[t]{4}{*}{ branch (Santorini) ${ }^{a}$} & Oldest rings $1-13$ & $3383 \pm 11$ & Hd-23599/24426 \\
\hline & Rings 14-37 & $3372 \pm 12$ & Hd-23587 \\
\hline & Rings 38-59 & $3349 \pm 12$ & Hd-23589 \\
\hline & Youngest rings $60-72$ & $3331 \pm 10$ & Hd-23588/24402 \\
\hline Akrotiri (Santorini) ${ }^{\mathrm{b}}$ & Average ${ }^{14} C$ date Akrotiri & $3350 \pm 10$ & \\
\hline \multirow{8}{*}{$\begin{array}{l}\text { Palaikastro (Crete) } \\
\text { tsunami deposits }^{\mathrm{c}}\end{array}$} & & & \\
\hline & Cattle bone, Promontory & $3310 \pm 35$ & GrA-30336 \\
\hline & Cattle bone, Promontory & $3390 \pm 35$ & GrA-30339 \\
\hline & Average ${ }^{14} C$ date Promontory & $3350 \pm 25$ & \\
\hline & Goat/sheep bone, near Building 6 & $3325 \pm 40$ & GrA-28991 \\
\hline & Goat/sheep bone, near Building 6 & $3345 \pm 40$ & GrA-29041 \\
\hline & Tooth, near Building 6 & $3385 \pm 40$ & GrA-29042 \\
\hline & Average ${ }^{14} C$ date near Building 6 & $3352 \pm 23$ & \\
\hline
\end{tabular}

${ }^{a}$ Based on data from Friedrich et al. 2006; ${ }^{b}$ based on data from Bronk Ramsey et al. 2004; ${ }^{c}$ based on data from Bruins et al. 2008, 2009.

radiocarbon dates for the growth rings (Friedrich et al. 2006 and supporting online material) with the individual dates from Palaikastro (Crete) on short-lived bone material. We see that the range of individual BP dates is very similar indeed (Table 1). How does the average radiocarbon date for the Minoan eruption, around $3350 \mathrm{BP}$, as measured on short-lived plant material from Akrotiri (Thera) and from Palaikastro (Crete), compare to the dates for the tree-rings on the Thera olive branch? Table 1 shows that the BP date for the youngest set of tree-rings (60-72) is $3331 \pm 10 \mathrm{BP}$. The midpoint is about 20 radiocarbon years younger than the midpoint of the average eruption date of $3350 \mathrm{BP}$. On the other hand, tree-rings 38-59 give the same result, $3349 \pm 12 \mathrm{BP}$, as the average from Akrotiri and Palaikastro.

The calibrated ages of the average radiocarbon dates for the Minoan eruption from Akrotiri and Palaikastro also deserve attention. The Akrotiri (Santorini) date, $3350 \pm 10$ $\mathrm{BP}$, gives a $2 \sigma$ calibrated age of $1683-1617 \mathrm{cal} \mathrm{BC}$, using the IntCal13 calibration curve (Reimer et al. 2013) and the OxCal v.4.2.2 calibration program (Bronk Ramsey 2001, 2013). This result excludes the sixteenth century $B C$ as too young for the eruption. The above $2 \sigma$ calibration result partly overlaps with the $2 \sigma$ wiggle-matched date by Friedrich et al. (2006) of $1627-1600 \mathrm{cal} \mathrm{BC}$ for the outer rings $60-72$. Yet the calibrated date for Akrotiri, inherently less precise, is somewhat older.

The average radiocarbon date, $3350 \pm 25 \mathrm{BP}$, for the Palaikastro Promontory gives a $2 \sigma$ calibrated age of $1735-1717$ (3.6\%), 1695-1606 (84.1\%), 1584-1545 (7.6\%) cal BC. The calibrated age range with the highest relative probability, $1695-1606 \mathrm{cal} \mathrm{BC}$, overlaps with rings 60-72 for the Thera olive branch, but is again slightly older. The average radiocarbon date, $3352 \pm 23 \mathrm{BP}$, for the Palaikastro main excavation site east of Building 6 gives a very similar $2 \sigma$ calibrated date of $1737-1715$ (4.5\%), 1695-1607 (85.0\%), 1584-1547 (5.9\%) cal BC. The youngest part of the Palaikastro $2 \sigma$ calibrated age ranges, 1584-1545 (7.6\%) 
and 1584-1547 (5.9\%) cal BC, respectively, both have a very low relative probability. Even these younger options are significantly older than the conventional archaeological age assessments for the Santorini eruption of around 1500 BC.

\section{Conclusions}

Most lines of reasoning raised by Cherubini et al. (above) against the high chronology for the Minoan Santorini eruption, based on ${ }^{14} \mathrm{C}$ dating, are shown to be flawed. Radiocarbon dates for the Minoan eruption from Akrotiri (Santorini) are identical to radiocarbon dates from Palaikastro (Crete). Therefore there is no old volcanic $\mathrm{CO}_{2}$ reservoir effect in the vegetation growing on Santorini. The similarity of the three datasets also bears witness that the Thera olive branch did not die a century before the eruption. Regarding archaeological relations with Egypt, Stratum C/2 at Tell el-Dab'a, containing pumice from the Minoan eruption, yielded ${ }^{14} \mathrm{C}$ dates that match the high chronology. The only issue that remains valid from the article by Cherubini et al. relates to their botanical field of expertise. It can be difficult to identify annual growth rings in olive trees, due to intra-annual wood density fluctuations. However, this problem cannot change the fact that the individual ${ }^{14} \mathrm{C}$ dates of the Thera olive branch match other ${ }^{14} \mathrm{C}$ dates (Akrotiri and Palaikastro) for the time of the Minoan eruption. If anything, the latter dates would allow for a slightly older date, but not a younger. Finally, it is important to make new detailed investigations on olive branches found at Thera in the Minoan tephra deposits, so that additional growth ring sequences may be studied and ${ }^{14} \mathrm{C}$ dated in order to further refine the high chronology. With regard to modern olive trees on Santorini and annual growth rings investigations, it would be very important to study the atomic bomb peak ${ }^{14} \mathrm{C}$ signal, which has a potential annual dating resolution (Quarta et al. 2005) for the period since AD 1955.

\section{References}

Arnan, X., B.C. López, J. Martínez-Vilalta, M. ESTORACH \& R. POYATOS. 2012. The age of monumental olive trees (Olea europaea) in northeastern Spain. Dendrochronologia 30: 11-14. http://dx.doi.org/10.1016/j.dendro.2011.02.002

BIETAK, M. \& F. HÖFLMAYER. 2007. Introduction: high and low chronology, in M. Bietak \& E. Czerny (ed.) The synchronisation of civilisations in the eastern Mediterranean in the second millennium B.C. III: 13-23. Vienna: Austrian Academy of Sciences.

Bronk Ramsey, C. 2001. Development of the radiocarbon calibration program. Radiocarbon 43: 355-63.

-2013. OxCal version 4.2.2. Available at http://c14.arch.ox.ac.uk/embed.php?File=oxcal.html

Bronk Ramsey, C., S.W. Manning \& M. Galimberti. 2004. Dating the volcanic eruption at Thera. Radiocarbon 46: 325-44.

Bruins, H.J. 2010. Dating Pharaonic Egypt. Science 328: 1489-90. http://dx.doi.org/10.1126/ science. 1191410

(C) Antiquity Publications Ltd.
Bruins, H.J., J.A. MacGillivray, C.E. Synolakis, C. Benjamini, J. Keller, H.J. Kisch, A. KlÜgel \& J. VAN DER PLICHT. 2008. Geoarchaeological tsunami deposits at Palaikastro (Crete) and the Late Minoan IA eruption of Santorini. Journal of Archaeological Science 35: 191-212. http://dx.doi.org/10.1016/ j.jas.2007.08.017

Bruins, H.J., J. VAN DER Plicht \& J.A. MacGILlivray. 2009. The Minoan Santorini eruption and tsunami deposits in Palaikastro (Crete): dating by geology, archaeology, ${ }^{14} \mathrm{C}$, and Egyptian chronology. Radiocarbon 51: 397-411.

Friedrich, W.L. \& J. HeINEMEIER. 2009. The Minoan eruption of Santorini radiocarbon dated to $1613 \pm 13$ BC, in D.A. Warburton (ed.) Time's up! Dating the Minoan eruption of Santorini: Acts of the Minoan Eruption Chronology Workshop, Sandbjerg, November 2007 (Monographs of the Danish Institute at Athens 10): 56-63. Athens: Danish Institute at Athens.

Friedrich, W.L., B. Kromer, M. Friedrich, J. Heinemeier, T. Pfeiffer \& S. Talamo. 2006. Santorini eruption radiocarbon dated to 1627-1600 B.C. Science 312: 548. http://dx.doi.org/10.1126/science.1125087 
Kutschera, W., M. Bietak, E.M. Wild, C. Bronk Ramsey, M. Dee, R. Golser, K. Kopetzky, P. Stadler, P. Steier, U. Thanheiser \& F. WENINGER. 2012. The chronology of Tell el-Daba: a crucial meeting point of ${ }^{14} \mathrm{C}$ dating, archaeology, and Egyptology in the $2^{\text {nd }}$ millennium BC. Radiocarbon 54: 407-22. http://dx.doi.org/ 10.2458/azu_js_rc.v54i3-4.16187

Quarta, G., M. D’Elia, D. Valzano \& L. CALCAGNILE. 2005. New bomb pulse radiocarbon records from annual tree rings in the northern hemisphere temperate region. Radiocarbon 47: 27-30.

Reimer, P.J., E. BARD, A. Bayliss, J.W. BeCK, P.G. BlackWell, C. Bronk Ramsey, C.E. Buck, H. Cheng, R.L. Edwards, M. Friedrich, P.M. Grootes, T.P. Guilderson, H. Haflidason, I. Hajdas, C. Hatté, T.J. Heaton, D.L. Hoffmann, A.G. Hogg, K.A. Hughen, K.F. Kaiser, B. Kromer, S.W. Manning, M. NiU, R.W. ReIMER, D.A. Richards, E.M. SCOTT, J.R. SOUTHON, R.A. STAFF, C.S.M. TURNEY \& J. VAN DER PLICHT. 2013. IntCal13 and Marine13 radiocarbon age calibration curves $0-50,000$ years cal BP. Radiocarbon 55: 1869-87.

http://dx.doi.org/10.2458/azu_js_rc.55.16947.
Rossi, L., L. Sebastiani, R. Tognetti, R. D’Andria, G. Morelli \& P. Cherubini. 2013. Tree-ring wood anatomy and stable isotopes show structural and functional adjustments in olive trees under different water availability. Plant and Soil 372: 567-79. http://dx.doi.org/10.1007/s11104-013-1759-0

Terral, J.F. \& A. Durand. 2006. Bio-archaeological evidence of olive tree (Olea europaea L.) irrigation during the Middle Ages in southern France and north eastern Spain. Journal of Archaeological Science 33: 718-24. http://dx.doi.org/10.1016/j.jas. 2005.10.004

\title{
The difficulties of dating olive wood
}

\author{
Peter Ian Kuniholm*
}

Olive wood is difficult to date for a variety of reasons, the most important of which is that one cannot tell visually what is an annual growth increment (usually referred to as a 'ring') and what is a sub-annual growth flush of which there may be any number in one growing season. (I have been able to count a dozen or more flushes in olive wood where the end of the growing season was somewhat more clearly marked than usual.) If one cannot determine the ring boundaries with certainty, one cannot do tree-ring dating, period. For Egyptologists reading this note, acacia is just as bad, and for the same reason. For 25 years I had a couple of sections of olive wood in my dendrochronology lab. Every term I would challenge students to tell me how many rings there were on them. No two students ever came up with the same answer and neither could I. An inspection of two different radii on the same piece also yielded widely varying results. (A side issue, not relevant here, is that the size of the ring in an olive tree does not necessarily reflect climatic conditions but rather the energies of the farmer or gardener who brings water to it. Thus olive is useless for purely dendrochronological cross-dating purposes. Also, olive trees tend to rot from the inside out, so that what seems like a very promising stem at first glance is hollow on

* Laboratory of Tree-Ring Research \& School of Anthropology, University of Arizona, Tucson, AZ 85721, USA (Email: peter.kuniholm@gmail.com)

(C) Antiquity Publications Ltd. 
the inside. The mythology of the Aegean is that olive trees can be thousands of years old. I have counted a hundred or so 'rings' (if they were indeed rings) on a handful of samples but no more.) What Friedrich and his co-workers (2006) needed to know was the exact ring count, regardless of the width of the rings. For successful radiocarbon wiggle-matching, if the radiocarbon laboratory is not given the precise ring-count between sampled sub-sections of the piece, any reported wiggle-match is immediately suspect. An approximation of the count just will not do. One or two or three or more missed (or missing) rings will skew the results by years or even decades. Since Friedrich and colleagues could not get a proper count visually, they tried high-tech alternatives, the most interesting to me being their attempt to use X-ray tomography. But here with olive wood the same problem applies. When the X-ray beam approaches an area of denser growth and smaller cells and signals that there is resistance, does this mean we are seeing the end of the growing season, or are we looking at just another sub-annual growth spurt? It matters little whether this was the main stem of the tree or a dead branch, which adds yet other chronological complications. The exact ring-count could not be verified by any of the attempted methods.

Thus Cherubini et al.'s contribution (above) is a necessary corrective to the Friedrich et al. exercise, however earnest and well-intentioned the latter may have been. Professor Doumas ought to be given some sort of archaeometric gold medal for his willingness to entertain yet another attempt to pin Santorini down. Surely, the Theran eruption must be by now the most intensely-examined event in all of archaeology. I have explored the Thera quarries, too, searching in vain for woody bits of pine or juniper, but when the Friedrich group did at last find a piece of wood, the Greek version of Murphy's Law decreed that it had to be an olive tree. The title of Gerald Cadogan's (1987) piece 'Unsteady date of a big bang' in Nature is still relevant.

\section{References}

Cadogan, G. 1987. Unsteady date of a big bang. Nature 328: 473. http://dx.doi.org/10.1038/ $328473 \mathrm{a} 0$

\author{
Friedrich, W.L., B. Kromer, M. Friedrich, J. \\ Heinemeier, T. Pfeiffer \& S. Talamo. 2006. \\ Santorini eruption radiocarbon dated to \\ 1627-1600 B.C. Science 312: 548. \\ http://dx.doi.org/10.1126/science.1125087
}

\section{A disastrous date}

\section{J. Alexander MacGillivray*}

Paolo Cherubini and colleagues have demonstrated convincingly that the identification of olive wood tree-rings from Santorini is 'practically impossible'. Thus, the single piece of evidence that might have persuaded some archaeologists to support the 'high' $1613 \pm 13 \mathrm{BC}$ date for the Theran eruption is hors de combat. The Theran olive-tree branch has gone the way of the Greenland Ice Core results of similar date and which enjoyed a similar devoted following until shown to be from a different eruption. Taken with Malcolm Wiener's explicit

*Ampelonon 50, Paiania 19002, Greece

(C) Antiquity Publications Ltd. 
exposé of the myriad shortcomings of ${ }^{14} \mathrm{C}$ dating, especially for this time period and event, these results take us back to where we were before the 'radiocarbon revolution', when the largest Holocene eruption in the ancient world happened as Minoan Crete enjoyed wideranging influence, perhaps even control, over the Aegean, when Late Minoan IA pottery styles proliferated, and Egypt was in the early stages of its New Kingdom period (Wiener 2012, 2013).

The powerful earthquakes, poisonous ash fall, tsunami and disruptive weather patterns which accompanied the Thera eruption severely impacted every society in the eastern Mediterranean. The physical effects found in the archaeological record provide a benchmark from which to calibrate our chronologies. The relative date is well established. We have plenty of evidence for the eruption's effects: tephra and tsunami deposits with pottery in Late Minoan IA styles in the Aegean, and Theran pumice from the Minoan eruption appearing first in the eastern Mediterranean in New Kingdom Egypt's Thutmoside period, when Late Cypriot IA:2 pottery styles were current in Egypt, the Levant, and even on Thera. Even the event's likely mythical record as Deucalion's Flood was set in the reign of Thutmose III (MacGillivray 2009).

With this physical relationship so well established, the absolute date-much prized by physicists-is irrelevant to archaeologists, who place events and relationships in a coherent order regardless of exact calendar years. ${ }^{14} \mathrm{C}$ and the quest for precise dates have distracted us from exploring the true nature and impact of this catastrophic and formative event in human history. By learning how ancient societies respond to natural disasters, we take lessons for our own time. This is what makes archaeology relevant. We don't care what year something happened. We care how and why it happened and what we can learn from it. Physicists will continue to argue the 'high' date because it fits their methodology. Archaeologists will continue to support the low date because it fits theirs. Neither camp needs the other's approval to carry on with their research, which is fortunate, because agreement appears to be a long, long way off.

\section{References}

MacGillivray, J.A. 2009. Thera, Hatshepsut, and the Keftiu: crisis and response in Egypt and the Aegean, in D.A. Warburton (ed.) Time's up! Dating the Minoan eruption of Santorini: Acts of the Minoan Eruption Chronology Workshop, Sandbjerg, November 2007 (Monographs of the Danish Institute at Athens 10): 148-64. Athens: Danish Institute at Athens.
Wiener, M.H. 2012. Problems in the measurement, calibration, analysis, and communication of radiocarbon dates (with special reference to the prehistory of the Aegean world). Radiocarbon 54: 423-34. http://dx.doi.org/10.2458/azu_js_rc. v54i3-4.16231

- 2013. Realities of power: the Minoan thalassocracy in historical perspective, in Robert B. Koehl (ed.) Amilla: the quest for excellence. Studies presented to Guenter Kopcke in celebration of his $75^{\text {th }}$ birthday (INSTAP Prehistory Monographs 43): 149-73. Philadelphia: Institute for Aegean Prehistory. 


\section{The olive tree-ring problematic dating}

\section{Paolo Cherubini ${ }^{1} \&$ Simcha Lev-Yadun ${ }^{2}$}

We are glad to see that our paper has stimulated a lively debate, and we acknowledge the appreciation of our work by Bietak, Kuniholm and MacGillivray as well as that of those who oppose our hypothesis (Bruins \& van der Plicht, Friedrich et al., all above). The enigma of the dating of the Santorini eruption is a long-lasting one, and because of its bearing on the dating of several eastern Mediterranean civilisations, has attracted significant attention. The potentially great importance of the Santorini olive branch used by Friedrich et al. (2006) was that it came from the site itself, and possibly belonged to the destruction layer. As such, the sincere and serious attempt to date it made by Friedrich et al. (2006) should be appreciated. Unfortunately, large olive branches may exist as dead limbs for a very long time and thus represent earlier periods.

We are dendrochronologists and tree biologists and we therefore focus our response on the tree-rings. Moreover, if the Santorini olive tree-ring data is not reliable there is therefore no in situ dating. All other indirect archaeological data emerging from sites outside Santorini, such as Crete and Egypt, and used for indirect dating of the Santorini eruption have their own inherited dating problems, as discussed by many others. We posit again that we consider the date of the Thera eruption based on the putative tree-ring sequence of a single olive tree (Friedrich et al. 2006) with great caution. As stated by Kuniholm (above), "[f] or successful radiocarbon wiggle-matching, if the radiocarbon laboratory is not given the precise ringcount between sampled sub-sections of the piece, any reported wiggle-match is immediately suspect. An approximation of the count just will not do. One or two or three or more missed (or missing) rings will skew the results by years or even decades", and so also will false or double rings, often found in Mediterranean trees (Cherubini et al. 2003, 2013).

The critical remarks by Bruins and van der Plicht and Friedrich et al. (above) indicate that publishing our original olive tree-ring findings (Cherubini et al. 2013) is of utmost importance. The fact that an evergreen Mediterranean tree species may form annual rings in one climatic area but not in another (e.g. Cherubini et al. 2003) is not always understood, and may cause confusion. Bruins and van der Plicht (above) didn't consider the flexible and very variable biology of cambial activity (and the resulting wood anatomy) in Mediterranean evergreens (e.g. Liphschitz \& Lev-Yadun 1986) and therefore cited papers that the first author of Cherubini et al. (above) published as a co-author (Rossi et al. 2013) or evaluated as the editor of the journal Dendrochronologia (Arnan et al. 2012) as contra evidence. However, the olive trees studied by Rossi et al. (2013) grew in a region with very low winter temperatures for cambial activity $\left(2-3^{\circ} \mathrm{C}\right)$, a temperature known to arrest cambial activity in Mediterranean evergreens (Liphschitz \& Lev-Yadun 1986 and citations therein).

\footnotetext{
${ }^{1}$ WSL Swiss Federal Institute for Forest, Snow and Landscape Research, CH-8903 Birmensdorf, Switzerland (Email:paolo.cherubini@wsl.ch; author for correspondence)

${ }^{2}$ Department of Biology \& Environment, Faculty of Natural Sciences, University of Haifa-Oranim, Tivon 36006, Israel (Email: levyadun@research.haifa.ac.il)

(C) Antiquity Publications Ltd.
} 
In Santorini, the low winter temperatures are around $10^{\circ} \mathrm{C}$, a much milder climate that allows for more flushes of growth and results in less pronounced seasonality (more false growth-rings). The study by Terral and Durand (2006) cited by Bruins and van der Plicht (above) does not prove anything concerning the possibility to determine whether olive growth-rings are indeed annual, but rather assumed that it is indeed so. As for Arnan et al. (2012: 11), they describe the problematic nature of olive tree-rings: "[t] ree-rings did not cross-date well, neither within nor between individuals", and only estimated the ages, a result that does not require safe identification of each and every growth-ring as needed for wiggle-match dating, the critical process in Friedrich et al. (2006).

The dendrochronological analysis of olive trees growing on Santorini (Cherubini et al. 2013) showed that the determination of their tree-ring number is impossible. Accordingly, caution should be taken with the dating by Friedrich et al. (2006) and their proposal cannot be used to discount a date range for the eruption of 1525-1490 BC as proposed by numerous other radiocarbon studies.

\section{References}

Arnan, X., B.C. Lopez, J. Martinez-Vilalta, M. ESTORACH \& R. POYATOS. 2012. The age of monumental olive trees (Olea europaea) in northeastern Spain. Dendrochronologia 30: 11-14. http://dx.doi.org/10.1016/j.dendro.2011.02.002

Cherubini, P., B.L. Gartner, R. Tognetti, O.U. BRÄKER, W. SCHOCH \& J.L. INNES. 2003. Identification, measurement and interpretation of tree rings in woody species from Mediterranean climates. Biological Reviews 78: 119-48. http://dx.doi.org/10.1017/S1464793102006000

Cherubini, P., T. Humbel, H. Beeckman, H. Gärtner, D. Mannes, C. Pearson, W. Schoch, R. TognetTi \& S. LeV-Yadun. 2013. Olive tree-ring problematic dating: a comparative analysis. PloS ONE 8: e54730. http://dx.doi.org/10.1371/journal.pone.0054730

Friedrich, W.L., B. Kromer, M. Friedrich, J. Heinemeier, T. Pfeiffer \& S. Talamo. 2006. Santorini eruption radiocarbon dated to 1627-1600 B.C. Science 312: 548. http://dx.doi.org/10.1126/science.1125087
LiPHSCHITZ, N. \& S. LeV-Yadun. 1986. Cambial activity of evergreen and seasonal dimorphics around the Mediterranean. IAWA Bulletin n.s. 7: 145-53.

Rossi, L., L. Sebastiani, R. Tognetti, R. D'Andria, G. Morelli \& P. Cherubini. 2013. Tree-ring wood anatomy and stable isotopes show structural and functional adjustments in olive trees under different water availability. Plant and Soil 372: 567-79. http://dx.doi.org/10.1007/s11104-013-1759-0

Terral, J.-F. \& A. Durand. 2006. Bio-archaeological evidence of olive tree (Olea europea L.) irrigation during the Middle Ages in southern France and north eastern Spain. Journal of Archaeological Science 33: 718-24. http://dx.doi.org/10.1016/j.jas.2005.10.004 